THE CULTURAL HERITAGE AS A RESOURCE IN CONFLICT RESOLUTION POSSIBILITIES AND CHALLENGES

O PATRIMÔNIO CULTURAL COMO UM RECURSO NA RESOLUÇÃO DE CONFLITOS: POSSIBILIDADES E DESAFIOS

Como citar este artigo:

WOLLENTZ, Gustav. The Cultural Heritage as a Resource in Conflict Resolution - Possibilities and challenges. Cadernos do Lepaarq, v. XVII, n.34, p. 74-90, Jul-Dez. 2020. 


\title{
The Cultural Heritage as a Resource in Conflict Resolution - Possibilities and challenges
}

\author{
Gustav Wollentz
}

\begin{abstract}
:
The goal of this article is to present some of the ways in which the cultural heritage can be used in conflict resolution and to which results, as well as to outline challenges. My method has been to read previous research concerning how the cultural heritage can be used in conflict resolution. I have also read the reports and articles available from the projects that I have deemed relevant. I have studied research projects, global organizations as well as smaller and more regional NGOs. This study shows that there are many ways in which the cultural heritage can be used as a resource in conflict resolution. However, for it to work one need also be aware of the various ways in which it can be misused. If those for whom a project is created are considered passive targets of a particular message concerning the past, the risk of losing control of that message will increase. The various meanings of the past as well as the people targeted, are not static but constantly in movement. I therefore argue that a process- oriented approach, preferably through dialogue and participation, would be a way to avoid a static presentation. This method could try to present history from as many perspectives as possible and begin with a focus on the local places and consider the inherently intangible aspects of heritage, to make it relatable, and from there highlight wider issues. Furthermore, the people planning it must be ready to get their own opinions about the heritage challenged by different perceptions, and in so doing, the inherently dissonant aspects of heritage should be seen as a resource rather than as a disturbance.
\end{abstract}

\section{Keywords:}

difficult heritage, sensible heritage, heritage futures.

\section{Resumo:}

O objetivo deste artigo é apresentar algumas das formas pelas quais o patrimônio cultural pode ser utilizado na resolução de conflitos e para quais resultados, bem como delinear desafios. Meu método tem sido ler pesquisas anteriores sobre como o patrimônio cultural pode ser usado na resolução de conflitos. Também li os relatórios e artigos disponíveis sobre os projetos que considerei relevantes. Tenho estudado projetos de pesquisa, organizações globais, bem como ONGs menores e mais regionais. Este estudo mostra que existem muitas maneiras pelas quais o patrimônio cultural pode ser usado como um recurso na resolução de conflitos. No entanto, para que funcione, é preciso estar ciente das várias maneiras pelas quais pode ser mal utilizado. Se aqueles para os quais um projeto é criado forem considerados alvos passivos de uma mensagem específica sobre o passado, o risco de perder o controle dessa mensagem aumentará. Os vários significados do passado, assim como as pessoas visadas, não são estáticos, mas em constante movimento. Portanto, argumento que uma abordagem orientada para o processo, de preferência por meio do diálogo e da participação, seria uma forma de evitar uma apresentação estática. Este método pode tentar apresentar a história de tantas perspectivas quanto possível e começar a considerar os aspectos inerentemente intangíveis do patrimônio com enfo que local para torná-los relacionáveis e, a partir daí, destacar questões mais amplas. Além disso, as pessoas que planejam o método devem estar prontas para obter suas próprias opiniões sobre o patrimônio desafiadas por diferentes percepções e, ao fazê-lo, os aspectos inerentemente dissonantes do patrimônio devem ser vistos como um recurso e não como uma perturbação.

\section{Palavras-chave:}

patrimônio difícil, patrimônio sensível, patrimônios futuros. 


\section{INTRODUCTION}

The goal of this article is to present some of the ways in which the cultural heritage can be used in conflict resolution and to which results, as well as to outline challenges. My method has been to read previous research concerning how the cultural heritage can be used in conflict resolution. I have also read the reports and articles available from the projects that I have deemed relevant. These projects can be focused on anything from theater, storytelling and time travels, where the cultural heritage has been involved in the sake of reconciliation. I have studied research projects, global organisations as well as smaller and more regional NGOs. My primary focus has been on projects connected to the European context. A substantial part of this research was undertaken in 2014 while working for Kalmar County Museum, and is available as a longer report here (Wollentz 2014). Further ideas expressed will be influenced by the fieldwork I carried out as part of my PhD project (2014-2018) at the Graduate School Human Development in Landscapes, Kiel University (Wollentz 2017a\&b, 2019, 2020), where I built from the bottom-up an understanding of difficult heritage, through conducted interviews. I have also been influenced by projects carried out within my current position as a researcher and project leader at the Nordic Centre of Heritage Learning and Creativity, particularly the project Heritage, Identity and Social Cohesion, financed by Nordplus Adult (Wollentz \& Kuhlefelt 2020), which is aiming at developing methods and mapping activities for social cohesion at museums and local heritage associations. ${ }^{1}$

\section{WHICH METHODS ARE WORKING?}

In this section I will present various methods that have been successfully used in conflict resolution. I will achieve this by dealing with one significant aspect at a time. This will also shed light on some of the dangers and possible pitfalls that can occur when working with these issues.

\section{PLURALIZING THE PAST}

When elaborating on the topic in 2007, Gregory Ashworth, John E. Tunbridge and Brian Graham, call for the need to "pluralise the past" in order for heritage to serve a function in reconciliation. Pluralising the past, they state, "is an unavoidable condition of post-modern societies (...). (Ashworth, Graham \& Tunbridge 2007: 212). In order to manage the "post-modern" condition of the "plural, hybrid and diverse societies worldwide" (212), they argue that heritage, just as identity, always needs to be pluralized and understood as multiple and overlapping (see also HyllandEriksen 2004; Hastrup 2010). This means that the so-called national narratives should preferably by challenged by different viewpoints (see for example: Ashworth et al 2007; Billingsley \& Wertsch 2011; Gustafsson 2011; Kutma 2012; Sebek 2010; 2011; Viejo- Rose 2011a\&b; Williams 2012; Wing 2011). As Karel Anthonie Bakker and Liana Müller write:

http://nckultur.org/projekt/heritage-identity-and-social-cohesion/ 


\begin{abstract}
"The authors argue (...) for open-ended heritage places where the emphasis is not necessarily on achieving consensus, but where contradictions, complexity and conflicts, due to inevitable differences in interpretation, may be continuously explored and debated, and seen as an opportunity for an increase in cultural vibrancy and cultural tolerance." (Bakker \& Müller 2010: 53-54).
\end{abstract}

This would resemble a way to find "other voices" through the cultural heritage, and let those speak, with a particular focus on the subaltern voices that have been, and may still be, silenced (see González-Ruibal 2008, 2019; Starzmann \& Roby eds 2016). The national narratives are naturally exclusive in character, that is, they include certain people (often connected to a geographical area and/or a certain ethnical majority) while excluding some, to form a strong sense of an exclusive national identity. Thus, national narratives include inherent silences (Trouillot 1995). These silences, unless recognized, can be highly oppressive (Wollentz et al 2020; 2020) and lead to counter reactions (Wollentz et al 2019). National narratives can be especially strong in so-called newly emerging national states, where there is a need to construct a grand history (Aronsson 2011). However, this form of rhetoric can also be found in the political agenda of various nationalistic parties that are spreading in present-day Europe (Niklasson \& Hølleland 2018). To foster reconciliation, the national narrative should preferably be challenged, and be made inclusive instead of exclusive (Billingsley \& Wertsch 2011).

What signifies the national narratives is that they do not include layers; they are one-sided, often chronological and has a sense of a fixed, static, historical truth, about them. As if the perceived development from then to today is natural, and that the present-day is an inevitable culmination of this process. This is certainly the result of an illusion based on an imagined exclusive and shared history (Anderson 1991; Balibar 2002). It is possible to contradict this perspective through the cultural heritage, and instead of presenting a fixed truth, focus on the multi-layered and contradictory pieces of the cultural heritage, where history is not presented as "linear" but rather as "chaotic" and "fragmentary". Inspired by the work of Pierre Nora (Nora 1989; Nora eds 2001), Dacia Viejo-Rose argues that a sense of historical memory can be applied to counter the grand narrative, presented by the state. She means that historical memory would take into account diversity and occasional divergence, without succumbing to the individual and deeply context-dependent memory (ViejoRose 2011a: 63).

Another method of challenging the national narrative would be to go from the particular to the universal. Cornelius Holtorf writes: “(...) the new cultural heritage can transcend cultural particularism by promoting values and virtues derived from humanism and a commitment to global solidarity." (Holtorf 2011: 14; see also Holtorf 2017) To achieve this, one possible way would be to begin with a focus on a particular issue or a local phenomenon, that can be "raised" to discuss universal human factors that would be relevant for everyone (see Westergren \& Hunner 2011). One example of where this method is being practiced is the Peace Museum in Guernica, Spain. The museum deals with the bombings of Guernica during the Spanish Civil War (1936 to 1939). However, Guernica is also used to discuss the issues of peace and war in the world today, with particular 
emphasize on the significance of equality and freedom for the establishment of peace in the world.

\section{A PROCESS-ORIENTED APPROACH}

With the realization that a static truth about the past should preferably be avoided, the importance does not lie in presenting facts to a passive "audience" but rather in the ideas and the thoughts that the cultural heritage wakes in people. Ashworth et al argues that the use of cultural heritage should address a moving target, with the realization that the past is in continuous creation and so are perspectives upon it (Ashworth et al 2007: 207). This demands an approach that is organic in character, rather than static, and there are various methods in which this can be achieved.

The Internacional Coalition of Sites of Conscience, which is a global network of historic sites, museums and memory initiatives, onnecting struggles of the past with human rights issues of the present, warns of the dangers in using the cultural heritage as a "blunt" political instrument. According to $\mathrm{SoC}$, this will encourage passivity. The method SoC promotes is not to tell people how to think through exhibitions, but make visitors shape their own answers through reflection and, importantly, through dialogue. To achieve this the museums and heritage sites present events nuanced from various perspectives without telling people which perspective would be the right one, and by drawing explicit connections to contemporary issues. They discuss the implications of the past for the present. Furthermore, SoC tries to create environments that involve ongoing debate and action. This includes dialogue through face-to-face discussion as well publishing, public tours and media attention. Museums and heritage sites transform into arenas for sharing ideas and promoting discussion and reflection. This will ultimately promote action in individuals instead of passivity, argues SoC (Ševčenko 2010, 2011).

This is clearly a statement partially directed against many politically motivated uses of the cultural heritage, where the building of one big expensive monument of commemoration tend to be constructed at the expanse of more lasting and process-oriented approaches. This is connected to the fact that political actions tend to value short-term affects over more lasting ones, mainly the effects until the next election. The immediate impact that can be clearly measured is at the center of attention, rather than the lasting ones. By promoting the process instead, one can also avoid the danger in "losing" control of the perceived symbolic value of a monument. How sites affect people are not easily controllable, and if the goal is to present a static statement the risk of losing control is unavoidably larger. A monument commemorating the victims of a conflict can also be perceived as a monument meant to induce guilt in those alive today that were not able to prevent it (ViejoRose 2011a). However, the fact that meanings are constantly developing, and in themselves plural in character, could be embraced instead of being perceived as a danger. To be able to embrace the contradictory and developing nature of "meanings", the constant "uncertainty" of heritage (Holtorf 2018; Wollentz et al 2020), dialogue between people is essential.

There are many projects which can be a perceived as dialogue-oriented. Between August 2003 and March 2011, The Outreach Team at English Heritage, involved community performances 
including theater and dance, in order to make people otherwise excluded from the cultural heritage participative through bodily movement and performance. One project involved people newly arrived in England, where people participated by taking parts in a theater discussing the meaning of home and the struggle to make home in a new environment. The process of participating in the play, of practicing and playing in front of an audience, and in the discussion of these individually relevant issues, promoted reflection among those involved concerning their own situation without providing a fixed answer (Levin 2010). Another project aimed at promoting discussion and reflection is Healing Through Remembering (HTR) in Ireland, concerning the troubles in Northern Ireland. ${ }^{2} \mathrm{HTR}$ arranges conversational workshops to promote discussions from as many perspectives as possible. Their starting point is that there are no set answers for dealing with the past (Wing 2011).

Another way of promoting dialogue is establishing networks of exchange. The Swedish NGO Cultural Heritage Without Borders, which has mainly been focusing on reconstructions of the cultural heritage in the Balkans, have developed a regional network for museums (the Balkan Museum Network), including a network for females in both managing and chief positions, Women's International Leadership Development (WILD), as well as a network for regional cooperation and exchange between NGOs (the South Eastern Europe Heritage Network) in the heritage sector (Kälvemark 2007; Ljungman \& Taboroff 2011; Stengård \& Legnér 2019). These networks are contributing to increased dialogue through a sharing of experiences.

Furthermore, within the project Heritage, Identity and Social Cohesion, financed by Nordplus Adult, mentioned above, which I am a project member of, multiple activities have been organized in Nordic and Baltic museums in order to simulate discussion, reflection and participation with diverse audiences, where the process is made central. Insights from these activities have highlighted that it takes time to build a relationship with a target group that is based on mutual trust and a sense of care. Therefore, it is necessary to allow and plan for such initiatives to take time, and avoid succumbing to the "fast-capitalist" ideology which unfortunately often underpins the institutions dealing with heritage as well as the funding bodies financing projects (Wollentz \& Kuhlefelt 2020; see also Kiddey 2020). It is therefore of significance to take time in building and planning the project together with those it involves. Furthermore, the ambition should be that the effects of the project will last longer than the actual life-span of the project. This means that the impact of a successful project will continue on into the future. The underlying key in the projects achieving a processoriented approach seems to be by dialogue promoting reflection and active participation, rather than focusing on a final outcome (see also May 2020; Fredheim 2020).

\section{THE LOCAL PERSPECTIVES}

If a project feels "forced down" upon people, the chances of it being successful decrease, and the risk of "losing" control of the meaning(s) it tries to address will increase. Ashworth et al 2007 argues that "Social and cultural cohesion depend upon the attainment of locally acceptable formulae

www.healingthroughremembering.org 
for the pluralization of the past." (Ashworth et al 2007: 211) This issue works both on a geographical as well as a social and cultural level. If the project is created and planned from far-away or from a different cultural point of view, without taking local perspectives in mind, it will be perceived as forced upon people from "outside". Furthermore, if it is created and planned by the people in power situations, the risk of it being felt as forced down upon people from "above" is large. It would form, what Laurajane Smith coined, an enforcement of the Authorized Heritage Discourse (AHD) (Smith 2006), instead of moving towards a more inclusive and bottom-up heritage discourse, as has been outlined in more recent conventions and frameworks (Kisić 2016).

Projects with the best of intentions might be misinterpreted and a schism between local and global intentions are prevailing in many instances. For example, there is a difference between the time needed to construct a bridge and the time needed to mourn its destruction and be willing to see it replaced. To grasp this in a balanced way, the local perspectives are essential (Viejo-Rose 2011b: 213). In the Balkans, statues of Hollywood movie stars like Rocky Balboa and Bruce Lee have been constructed, the last one in the city of Mostar, in Bosnia and Herzegovina (Raspudic 2004; Makas 2007; Wollentz 2017a, 2020). This can be approached as an example of where people, quite contradictory, turn outside to find a shared identity because the history within the area is still torn by recently experienced conflict. It represents an escape from dealing with the troubled past within their own geographical area. The initiative is certainly ingenious within a globalized world where culture is increasingly moving beyond the nation-state while individuals are still being focused on producing locality within their specific contexts (neighbourhoods) (Appaduari 1996). Furthermore, it shows an unwillingness to comply with an imposed vision (from above) of heritage and its reconstruction (Viejo-Rose 2011b: 213).

When listening to local perspectives in developing the project, local places as well as local traditions, dances, and storytelling become crucial factors, what UNESCO would label as intangible heritage, through the distinction proposed in UNESCO's "Convention for the Safeguarding of Intangible Cultural Heritage" (2003). However, before we continue the elaboration, it is important to keep in mind that the division between tangible and intangible heritage can be arbitrary (Smith 2006; Harrison \& Rose 2010; Poulios 2011; Harrison 2015), and that "heritage" as a concept is connected to modernity and the so-called "Western world" and runs the risk of being detached from how these sites and ceremonies are being understood and used locally (Smith \& Waterton 2009). Clearly, UNESCO's "Convention for the Safeguarding of Intangible Cultural Heritage" was born out of an increased concern within UNESCO to acknowledge other forms of heritage than simply the ones recognized through the Authorized Heritage Discourse (AHD) (inherent monumentality, beauty and age), through acknowledging other ways of "doing" and "performing" heritage, including traditions such as specific dances or traditional cuisines. However, the separation hides the fact that all forms of tangible heritage include intangible aspects making it meaningful, which may cause significant complications if not being recognized (Poulios 2011).

The global organization Bridging Ages has focused on local places and identities through Time Travels, using the method called Historic Environment Educational (HEE). The method connects 
history to everyday life and communities of today. By using the local and relatable as a starting point, larger issues can be dealt with. It is a matter of locating the individual within the history, and ultimately, within the world. Bridging Ages hopes to achieve this through Time Travels. Here, the physical effects of turning into someone else within a local and relatable landscape and history is used (Westergren and Wollentz 2018), thoroughly breaking down any clear-cut borders between tangible and intangible heritage.

\section{DISSONANCE AS INHERENT}

The dissonance in heritage, i.e. the multiple and oftentimes contradictory meanings that heritage holds, should not be seen as a disturbance in need of being solved, but as an inherent feature of heritage, and as a potential positive value (Wollentz 2017b). As written by Višnja Kisić:

\footnotetext{
“(...) dissonance can empower de-naturalization of heritage, foster critical thinking and create opportunities for intense intercultural mediation. Therefore, the tension and energy that dissonance in heritage brings is not necessarily the energy of violence, but the energy of action and change, which could be used for the good." (Kisić 2016: 31).
}

By de-naturalizing heritage through a recognition of its dissonance, objects and monuments will no longer be seen as heritage based on inherent and pre-determined values, but as heritage based on cultural and social processes that are not self-given nor can be taken for granted. This may lead us to pose fundamental questions surrounding heritage that would otherwise not have been asked (Holtorf and Högberg 2013; Harrison 2015; Högberg et al 2017; Harrison et al 2020), and help us move away from seeing heritage as a carrier of static and essential cultures, ethnicities or identities that often underpin ethnic conflict and war (Brubaker 2004; Herscher 2010). This is an urgent concern, since research has demonstrated that the heritage sector is still largely directed towards, and functions within, essential ideas of people and cultures (Högberg 2016).

\section{THE PAST AS PAST}

To focus on the local and recent history and from there go to the global is an excellent method to reach individuals. However, when the recent past is filled with conflict, the local history is a highly sensitive issue. As previously mentioned, the issue of time is essential, and in cases of recent turmoil, the best method for reconciliation might not be to address the past as individually relatable; but rather the past as past with the hope of it staying that way. The need to address the past is not necessarily because it will be used for various motives, but because people can neither progress nor forgive while it is being silenced. In such circumstances the past can be approached as an "absent present" (Buchli \& Lucas 2001), i.e. the past is not addressed based on its similarities with the present but because of its differences and the will for such things never to occur again (Filippucci 2012). However, this will only be a viable method if the war crimes committed have been adequately adressed and those responsible punished. Otherwise, presenting the past as past will be seen as a 
deliberate attempt of muddying the waters of responsibility.

\section{HOW CAN THE CULTURAL HERITAGE MAKE A DIFFERENCE?}

In this section I will discuss how the cultural heritage can make a difference in conflict resolution, based on the projects and research carried out. In general it seems to be harder to present concrete examples of how the cultural heritage can bring reconciliation. More research have been dealing with how to practically use the cultural heritage in conflict resolution than in examining the results of the work carried out. However, there are arguments concerning the positive effects of the cultural heritage, and I will present them here.

\section{THE IMPORTANCE IN REMEMBERING IN ORDER TO MOVE FORWARD}

One significant factor in the use of the cultural heritage is the perceived importance in remembering, and this can take many forms. First of all, there can be a moral sense of duty to those dead; that the people alive today have a debt to remember those that are gone (Filippucci 2012). If the dead individuals somehow have been forgotten within the national narrative, this duty can build into a powerful force wanting their stories to be acknowledged in order right a historical wrongdoing. Refusing to address a troubled past will not make it disappear. As Dacia Viejo-Rose argues based on her studies on how Spain handled the cultural heritage after the Spanish Civil War: partial memories do not erase the "other" memory, but they do infuse it with an element of confrontation (Viejo-Rose 2011b: 206). To silence certain voices will only contribute to prolong a division and could lead to violent actions between the repressed and those in control of the narrative. A step towards reconciliation would be to address these muted voices and give them the freedom to mourn and share their experiences. Remembrance can be of significance because the need to move on is prevailing, and as long as the past is not addressed there is no possibility to neither forgive nor move on.

\section{NOSTALGIA AS A BASIS FOR AN ALTERNATIVE FUTURE}

The issue of moving forward leads us to the way the heritage can be drawn upon in order to envision a different future, i.e. the future-assembling capacities of heritage (Harrison 2015; Harrison et al 2020; Wollentz 2017a). In fact, Svetlana Boym (Boym 2001) has emphasized how a certain form of nostalgia can form a basis for action and be used in order to shape new futures, contrasting against traditional understandings of nostalgia as connected to passivity and inaction. Such ideas have also been applied in heritage (Smith \& Campbell 2017) and has a strong relevance in Former Yugoslavia where I have conducted field work (Petrović, 2007; Palmberger, 2008; Kurtović and Hromadžić, 2017; Maksimović, 2017). Here, the post-war heritage of Socialist Yugoslavia (1945-1991) is sometimes actively drawn upon in order to challenge the current ethno-national employment of heritage which 
enforces ethnic division. Instead, this employment of the socialist past attempts to carve out an alternative future of a belonging that moves beyond ethnic division (Wollentz 2017a; 2020).

\section{PROMOTING UNDERSTANDING}

If cultural identities are perceived as flexible and vibrant, heritage has the potential to bridge distances between human beings instead of increasing them. This can be achieved with a focus on human beings and cultures as multi-layered and complex, instead of presenting human beings with fixed identities within fixed cultures. As Liz Ševčenko writes:

\footnotetext{
"Rather than reacting to conflict over our heritage sites defensively, we could perhaps identify the issues underlying the conflict and offer our sites as a resource for addressing them inasmuch as heritage sites have unique resources for helping people to deal with difference, examples of how people dealt with conflict in the past, a human connection to people in other circumstances and a trusted space for learning new perspectives." (Ševčenko 2010: 21).
}

If the cultural heritage is used to emotionally involve people (by the method of for example theater, time travels our museums) in other individuals' views of life there is potential for increasing understanding (Sebek 2010; Westergren \& Hunner 2011; Westergren \& Wollentz 2018). When the project is successful, the people involved will hopefully come to a realization through the personally relatable that, despite cultural differences, there are more aspects that unites human beings than disunites them.

The particular meaning behind the cultural heritage is not necessarily of primary significance when it is involved in promoting understanding between human beings. For example, Cornelius Holtorf writes: "Cultural heritage can also provide opportunities for communities to care for something fragile together and hence promote a sense of responsibility, persistence and respect for the knowledge and values of fellow residents or citizens. Social cohesion is thus advanced through the process of caring for the heritage, not through a celebration of any particular meaning it may have an (Holtorf 2011: 13). Here, the act of caring for something together with other people, and not the meaning it self, is a factor increasing understanding between human beings.

\section{INCREASING CRITICAL THINKING}

Nenad Sebek, from Joint History Project (JHP), argues that the complexities within the cultural heritage can be used to increase critical thinking. Ultimately, she means that "Critical analyzing will form a participative adult who is capable of forming and voicing democratic opinions." (Sebek 2010: 121) A similar argument is put forward by Liz Ševčenko who writes that awareness of the present will increase the will in people to actively fight for change. For Sites of Conscience (SoC), the value in the cultural heritage lies in its potential to encourage people to actively participate in creating a more democratic world (Ševčenko 2010, 2011). Their motto is "from memory to action". Here, the cultural heritage is not valued for its more "passive" potential to let people "move on" or join together in 
"caring" about something fragile, but for its potential to form an active, critical and democratic individual.

\section{DISCUSSION}

This study shows that there are many ways in which the cultural heritage can be used as a resource in conflict resolution. However, for it to work one need also be aware of the various ways in which it can be misused. If those for whom a project is created are considered passive targets of a particular message concerning the past, the risk of losing control of that message will increase. The various meanings of the past as well as the people targeted, are not static but constantly in movement. I therefore argue that a process- oriented approach, preferably through dialogue and participation, would be a way to avoid a static presentation. This method could try to present history from as many perspectives as possible, and begin with a focus on the local places and consider the inherently intangible aspects of heritage, to make it relatable, and from there highlight wider issues. The project may be developed through dialogue together with those the projects concern. Furthermore, the people planning it must be ready to get their own opinions about the cultural heritage challenged by different perceptions, and in so doing, the inherently dissonant aspects of heritage should be seen as a resource rather than as a disturbance.

However, it is of significance to underline that there are no fixed "model" for how the cultural heritage can be applied to foster reconciliation. The projects have to be context-dependent. First of all, the issue of time is essential for how the cultural heritage should be used. There is a difference between the need for mourning the destruction of a cultural heritage and the will to see it replaced. Furthermore, when the recent past is filled with extreme violence, it might not be preferable to present history as local and personally relatable. Rather, when the recent past is still a half-open wound, it could be possible to present the past as past, which can be condemned for the wellbeing of global humanitarian values. However, for this to be successful, historical injustices need to have been adressed and those responsible for war crimes need to have been adequately punished. Otherwise, a top-down attempt of presenting the past as an alien evil will simply be seen as an attempt of sidestepping responsibility. This emphasizes the need to be sensitive to the political and social situations in the countries when dealing with the past, and work with the various methods bottom-up instead of top-down.

It is somewhat difficult to present the actual effects that the cultural heritage has in bringing reconciliation. One explanation is that the effects are difficult to measure in a scientific way, since they work alongside and are highly entangled with other important factors in society. Furthermore, they can be valuable on an unconscious level. That is, the value is not always clearly articulated. Using Council of Europe's "Faro Convention" (Convention on the Value of Cultural Heritage for Society) from 2005 as an important focal point, many researches argue for the importance of cultural heritage in order to create a peaceful and democratic society. Heritage can be used to give voice to people who have been silenced in history, thus making it possible to forgive past atrocities and move 
on. It can be used to carve out on alternative future different from the one of ethnic conflict and division. It can be used to promote understanding, where the meaning in the heritage itself can be less relevant than the actual act of caring for it. Finally, it can be used in forming a participative and critically thinking individual.

\section{CHALLENGES}

These results indicate that the field could improve in following up the impacts of their projects. After a finished project it is valuable to study the notable results and consider what can be taught from those. The question of how to study these effects need to be addressed. In what way can we possibly study the benefits of the cultural heritage for bringing reconciliation? These are important questions because we need to articulate the value of the cultural heritage in a convincing way. Right extremism with racist inclinations are spreading all over Europe and the need for forgiveness, understanding, democratic values and critically thinking individuals are therefor as high now as it has ever been. Especially since those very parties are using the cultural heritage for the opposite reason; to present the picture of a uniform and static cultural identity (Gustafsson \& Karlsson 2011; Niklasson \& Hølleland 2018).

The past should preferably not be used as a blunt political instrument to present a static message. Rather, the past could be presented as complex and nuanced filled with individuals rather than static cultures. Furthermore, the most important thing is undoubtedly to allow every voice to be heard, and from there, mutual understanding and forgiveness can hopefully be found. Nevertheless, however commendable and inspiring, criticism towards a certain degree of innocent post-modern naiveté within pluralizing enterprises can also be made, in that presenting perspectives may not be enough (see Gonzalez-Ruibal et al 2018 and the following debate). As expressed by Alfredo Gonzalez-Ruibal: "As engaged researchers, we have to listen to all voices but privilege narratives that are fair to the facts, politically critical, and that do not balk at dissension or the lack of consensus." (Gonzalez-Ruibal 2017: 298)

The inherent tension between allowing every voice to be heard, while still advocating those voices supporting human rights issues, and not muddying crucial issues such as where responsibility is placed for the acts of war-crimes, is certainly neither self-given nor free of conflict within an overall aim of pluralising the past. Therefore, even if heritage should allow every voice to be heard, all perspectives cannot be presented nor accepted as equally valid. Perhaps it is within that realization that the greatest challenge lies. 


\section{REFERENCES}

ANDERSON, B. Den föreställda gemenskapen: reflexioner kring nationalismens ursprung och spridning. Göteborg: Daidalos. 1991.

APPADURAI, A. Modernity at large: cultural dimensions of globalization. Minneapolis, University of Min-nesota Press. 1996.

ARONSSON, P. Explaining National Museums: Exploring comparative approaches to the study of national museums. In: Knell, Simon J. (ed.) National museums: new studies from around the world. Abingdon : Routledge. Pp. 29-54. 2011.

ASHWORTH, G. J., B. J. GRAHAM \& J. E. TUNBRIDGE, J. E. Pluralising pasts: heritage, identity and place in multicultural societies. London: Pluto Press. 2007.

BAKKER, K., A., \& L. MÜLLER. Intangible Heritage and Community Identity in Post-Apartheid South Africa. Museum International. No. 245-246 (Vol. 62, No. 1-2, 2010). Pp. 48-56. 2010.

BALIBAR, É. Nationsformen: Historia och ideology. In: Étiene B. \& Immanuel W. (red.) Ras, Nation, KLASS, Boförlaget Daidalos AB, Uddevalla. 2002.

BOYM, S. The future of nostalgia. New York, Basic Books. 2001.

BRUBAKER, R. Ethnicity without groups. Cambridge, Harvard University Press. 2004.

BUCHLI, V. \& G. LUCAS. Archaeologies of the Contemporary Past. Routledge. 2001.

FILIPPUCCI, P. Archaeology and the anthropology of memory: Takes on the recent past. In: Duncan, G. \& Thomas, Y. (eds.) Archaeology and anthropology: understanding similarities, exploring differences. Oxford: Oxbow Books Ltd. Pp. 69-83. 2012.

FREDHEIM, H. Decoupling 'Open' and 'Ethical' Archaeologies: Rethinking Deficits and Expertise for Ethical Public Participation in Archaeology and Heritage. Norwegian Archaeological Review. (Online first). 2020.

GUSTAFSSON, B. The Meaning of Places through Stories: A Pedagogical Perspective. In: GUSTAFSSON, B., HOLTORF, C., WESTERGREN, E.(eds.) Museum International Volume 63, Issue 1-2. Pp. 63-69. 2011.

GUSTAFSSON, A. \& H. KARLSSON. A Spectre is Haunting Swedish Archaeology - The Spectre of Politics. Archaeology, Cultural Heritage and the Present Political Situation in Sweden. Current Swedish Ar-chaeology 19. Pp. 11-36. 2011.

HARRISON, R. Beyond "Natural" and "Cultural" Heritage: Toward an Ontological Politics of Heritage in the Age of Anthropocene. Heritage \& Society 8 (1). Pp. 24-42. 2015.

HARRISON, R. \& D. ROSE. Intangible Heritage. In: R. Harrion. (ed.) Understanding Heritage and Memory. Edited byManchester: Manchester University Press. Pp. 238-276. 2010.

HARRISON, R., C. DESILVEY, C. HOLTORF, S. MACDONALD, N. BARTOLINI, E. BREITHOFF, H. FREDHEIM, A. LYONS, S. MAY, J. MORGAN, \& S. PENROSE. Heritage Futures Comparative Approaches to Natural and Cultural Heritage Practices. UCL Press. 2020.

HASTRUP, K. Kultur- Den flexibla gemenskapen. Lund: Studentlitteratur. 2010. 
HERSCHER, A. Violence taking place: the architecture of the Kosovo conflict. California, Stanford University Press. 2010.

HOLTORF, C. The Changing Contribution of Cultural Heritage to Society. In: B. Gustafsson, C. 2011. HOLTORF, E. WESTERGREN. (eds.) Museum International Volume 63, Issue 1-2. Pp. 8-16. 2011.

HOLTORF, C. Cultural heritage beyond culturalism. Published online at "Heritage for transformation": https://heritagefortransformation.wordpress.com/2017/11/29/ cultural-heritage-beyond-culturalism/ 2017.

HOLTORF, C. Embracing change: how cultural resilience is increased through cultural heritage. World Archaeology 50 (4). Pp. 639-650. 2018.

HOLTORF, C. AND A. HÖGBERG. Heritage Futures and the future of heritage. Counterpoint: Essays in Ar-chaeology and Heritage Studies in Honour of Professor Kristian Kristiansen. Edited by S. Bergerbrant and S. Sabati-ni. BAR Int. Ser. 2508. Archaeopress, Oxford. Pp. 739746. 2013.

HYLLAND-ERIKSEN, T. Rötter och fötter : Identitet $i$ en föränderlig tid. Nya Doxa. 2004.

HÖGBERG, A. To renegotiate heritage and citizenship beyond essentialism. Archaeological Dialogues 23 (1). Pp. 39-48. 2016.

HÖGBERG, A., C. HOLTORF., S. MAY AND G. WOLLENTZ. No future in archaeological heritage manage-ment? World archaeology 49 (5). Pp. 639-647. 2017.

KIDDEY, R. I'Il Tell You What I Want, What I Really, Really Want! Open Archaeology that Is Collaborative, Participatory, Public, and Feminist. Norwegian Archaeological Review. 2020.

KISIĆ, V. Governing Heritage Dissonance: Promises and Realities of Selected Cultural Policies. European Cultural Foundation. 2016.

KUTMA, K. Contested Memory and Re-configured Master Narratives: Museum Institution in Totalitarian Regimes. In: POULOT, P., GUIRAL, J. M. L., \& BODENSTEIN, F. (eds.). National Museums and the Negotiation of Difficult Pasts. EuNaMus Report No. 8. Published by Link̈ping University Electronic Press. Pp. 79-90. 2012.

KURTOVIĆ, L. \& A. HROMADŽIĆ. Cannibal states, empty bellies: Protest, history and political imagination in post-Dayton Bosnia. Critique of Anthropology 37(3). Pp. 262-296. 2017.

KÄLVEMARK, T. Cultural Heritage for Peace and Reconciliation: An evaluation of Cultural Heritage without Borders (ChwB). Unpublished report available at http://chwb.org 2007.

LEVIN, M. Community Engagement with Heritage. In: SVANBERG, F. (ed.). The Museum as Forum and Actor. The Museum of National Antiquities, Stockholm. Pp. 61-76. 2010.

LJUNGMAN, C. \& J. TABOROFF. Evaluation of Cultural Heritage without Borders (2008-2011). Unpublished report available at http://chwb.org_2011.

MAKAŠ, E. Representing Competing Identities: Building and Rebuilding in Postwar Mostar, BosniaHercegovina. Unpublished PhD thesis, Cornell University. 2007.

MAKSIMOVIĆ, M. Unattainable past, unsatisfying present - Yugonostalgia: an omen of a better 
future? Nationalities Papers 45(6). Pp. 1066-1081. 2017.

MAY, S. Heritage, endangerment and participation: alternative futures in the Lake District. International Journal of Heritage Studies 26 (1). Pp. 71-86. 2020.

NIKLASSON, E. \& HØLLELAND, H. The Scandinavian far-right and the new politicisation of heritage. Journal of Social Archaeology 18 (2). Pp. 121-148. 2018.

NORA, P. Between Memory and History: Les Lieux de Mémoire. Memory and Counter Memory 26, 7-67 24. 1989.

NORA, P. Rethinking France. Les Lieux de Mémoire. Volume 1. The State. The University of Chicago Press. 2001.

PALMBERGER, M. Nostalgia matters: nostalgia for Yugoslavia as potential vision for a better future. Sociologija, Vol. L (2008) (4). Pp. 355-370. 2008.

PETROVIĆ, T. The territory of the former Yugoslavia in the "mental maps" of former Yugoslavs: Nostalgia for space. Sprawy Narodowościowe 31. Pp. 263-273. 2007.

POULIOS, I. Is Every Heritage Site a 'Living' One? Linking Conservation to Communities' Association with Sites. The Historic Environment 2 (2). Pp. 144-156. 2011.

RASPUDIĆ, N. The Monument of Bruce Lee - Yes and Why? Unpublished speech held November 5, 2004.

STENGÅRD, M. \& LEGNER, M. Funder and facilitator: Swedish development aid aimed at cultural heritage in Bosnia and Herzegovina 1995-2008. International Journal of Cultural Policy. DOI: 10.1080/10286632.2019.1621302 [online first] 2019.

GONZÁLEZ-RUIBAL, A. Time to Destroy. An Archaeology of Supermodernity. Current Anthropology 49 (2). Pp. 247-279. 2008.

GONZÁLEZ-RUIBAL, A. Excavating Memory, Burying History. Lessons from the Spanish Civil War. Between Memory Sites and Memory Networks New Archaeological and Historical Perspectives, Berlin, Reihe: Berlin Studies of the Ancient World. Vol. 45. Pp. 279-302. 2017.

GONZÁLEZ-RUIBAL, A. An Archaeology of the Contemporary Era: The Age of Destruction. Routledge. 2020.

GONZÁLEZ-RUIBAL, A., P.A. GONZÁLEZ AND F. CRIADO-BOADO. Against reactionary populism: towards a new public archaeology. Antiquity 92 (362). Pp. 507-515. 2018.

SEBEK, N. How Turkish is your Coffee. The SEE Joint History Project. In: Svanberg, F. (ed.). The Museum as Forum and Actor. The Museum of National Antiquities, Stockholm. Pp. 115124. 2010.

ŠEVČENKǑ, L. Sites of Conscience: new approaches to conflicted memory. Museum International. No. 245-246 (Vol. 62, No. 1-2, 2010). Pp. 20-25. 2010.

ŠEVČENKǑ, L. Sites of Conscience: Heritage of and for Human Rights. In: Anheier, H. \& Isar, Y. R. (ed.) Heritage, Memory and Identity. Pp. 114-123. 2011.

SMITH, L. Uses of heritage. New York, Routledge. 2006. 
SMITH, L. \& CAMPBELL, G. 'Nostalgia for the future': memory, nostalgia and the politics of class. International Journal of Heritage Studies 23(7). Pp. 612-627. 2017.

SMITH, L. \& WATERTON, E. There is no such thing as heritage. Taking Archaeology out of Heritage, edited by L. Smith and E. Waterton. Pp. 10-27. Cambridge, Cambridge Scholars Publishing. 2009.

STARZMANN, M. T. \& ROBY, J. R.. Excavating Memory. Sites of remembering and forgetting. Florida, University Press of Florida. 2016.

TROUILLOT, M.R. Silencing the past: power and the production of history. Boston, Mass., Beacon Press. 1995.

TUNBRIDGE, J. E. \& ASHWORTH, G. J. Dissonant heritage: the management of the past as a resource in conflict. Wiley, Chichester. 1996.

WERTSCH, J., BILLINGSLEY, D. M. The Role of Narratives in Commemoration: Remembering as Mediated Action. In: Anheier, H. \& Isar, Y. R. (eds.) Heritage, Memory and Identity. Pp. 25-38. 2011.

VIEJO-ROSE, D. Destruction and Reconstruction of Heritage: Impacts on Memory and Identity. In: Anheier, H. \& Isar, Y. R. (eds.) Heritage, Memory and Identity. Pp. 53-69. 2011a.

VIEJO-ROSE, D. Reconstructing Spain: cultural heritage and memory after Civil War. Brighton: Sussex Academic. 2011b.

WESTERGREN, E. \& HUNNER, J. Engaging the Present through the Past. In: GUSTAFSSON, B., HOLTORF, C., WESTERGREN, E. (eds.) Museum International Volume 63, Issue 1-2. Pp. 119-129. 2011.

WESTERgREN, E. \& WOLLENTZ, G. (eds). The Time Travel Method - In the Service of Society and its Development. Kalmar, Kalmar County Museum. 2018.

WILLIAMS, P. Treading Difficult Ground: The Effort to Establish Russia's First National Gulag Museum. In: Poulot, P., Guiral, J. M. L., \& Bodenstein, F. (eds.). National Museums and the Negotiation of Difficult Pasts. EuNaMus Report No. 8. Published by Link̈ping University Electronic Press. Pp. 111-121. 2012.

WING, L. Dealing with the Past: shared and contested narratives in 'post-conflict' Northern Ireland. Museum International. No. 245-246 (Vol. 62, No. 1-2, 2010). Pp. 31-36. 2010.

WOLLENTZ, G. The Cultural Heritage as a Resource in Conflict Resolution: An Overview of the Field. Kalmar County Museum. http://bridgingages.com/site/assets/files/1516/cultural_ heritage_in_conflict_resolution.pdf [02 11 2020]. 2014.

WOLLENTZ, G. Making a home in Mostar: Heritage and the Temporalities of Belonging. International Journal of Heritage Studies 23 (10). Pp. 928-945. 2017a.

WOLLENTZ, G. Prehistoric violence as difficult heritage: Sandby borg - a place of avoidance and belonging. Current Swedish Archaeology 25. Pp. 199-226. 2017b.

WOLLENTZ, G. Conflicted memorials and the need to look forward. The interplay between remembering and forgetting in Mostar and on the Kosovo Field. In: M. L. S. Sørensen, D. Viejo-Rosé and P. Filippucci. (eds.) Memorials in the Aftermath of Armed Conflict: From History to Heritage. Palgrave Macmillan. Pp. 159-182. 2019. 
WOLLENTZ, G. Landscapes of Difficult Heritage. Palgrave Macmillan. 2020.

WOLLENTZ, G., M. BARIŠIĆ AND N. SAMMAR. Youth Activism and Dignity in Post-war Mostar, Envisioning a Shared Future through Heritage. Challenging the Representation of Ethnically Divided CITIES: PERSPECTIVES FROM MOSTAR. SPACE AND POLITY 23 (2). PP. 197-215. 2019.

WOLLENTZ, G., S. MAY, C. HOLTORF AND A. HÖGBERG. Toxic Heritage: Uncertain and Unsafe. Heritage Futures. Comparative Approaches to Natural and Cultural Heritage Practices In: Harrison, R., DeSilvey, C., Holfort, C., Macdonald, S., Bartolini, N., Breithoff, E., Fredheim, H., Lyons, A., May, S., Morgan, J., Penrose, S., with contributions by Högberg, A., and Wollentz, G. (eds.). UCL Press. Pp. 294-312. 2020.

WOLLENTZ, G. \& H. KUHLEFELT. Heritage as a process of connecting - pluralism and diversity in Nordic and Baltic museums. International Journal of Heritage Studies. (online first). 2020.

\section{INTERNET SOURCES}

Healing Through Remembering. www.healingthroughremembering.org. Accessed 02/11 2020.

NCK. http://nckultur.org/projekt/heritage-identity-and-social-cohesion/. Accessed 02/11 2020. 